\title{
Learning from Experience: The Impact of Research About Family Support Programs on Public Policy
}

\section{Citation}

Martha Minow Learning from Experience: The Impact of Research About Family Support Programs on Public Policy, 143 U. Pa. L. Rev. 221 (1994).

\section{Published Version}

http://scholarship.law.upenn.edu/penn_law_review/vol143/iss1/7/

\section{Permanent link}

http://nrs.harvard.edu/urn-3:HUL.InstRepos:12933377

\section{Terms of Use}

This article was downloaded from Harvard University's DASH repository, and is made available under the terms and conditions applicable to Other Posted Material, as set forth at http:// nrs.harvard.edu/urn-3:HUL.InstRepos:dash.current.terms-of-use\#LAA

\section{Share Your Story}

The Harvard community has made this article openly available.

Please share how this access benefits you. Submit a story.

Accessibility 


\section{LEARNING FROM EXPERIENCE: THE IMPACT \\ OF RESEARCH ABOUT FAMILY SUPPORT \\ PROGRAMS ON PUBLIC POLICY}

\section{MARTHA MINOW†}

Do public policies reflect the experiences of people who implement them or those who are supposed to benefit from them? This kind of question may seem remote from the work of an appellate judge, and yet Judge David Bazelon's abiding interest in the links and gaps between social science and law grew from concern with this basic question. I will focus on a particular social welfare program as I explore the failure of public policy to respond to social science findings. For those who did not know Judge Bazelon, however, here is a fuller explanation of why I chose this topic for this symposium honoring the Judge.

One day while I was clerking for Judge Bazelon, a classmate clerking at another court conjectured that the appellate world of the D.C. Circuit was narrow, given its focus on the records of administrative actions and its cloistered setting. I found myself replying that the world of Judge Bazelon was the opposite of narrow. I regaled my friend with the list of journalists, scientists, social scientists, and authors who had come either to chambers or to lunch with the Judge and his clerks to discuss topics ranging from the psychological dimensions of risk assessment to international responses to American television. Indeed, it was a heady world. Judge Bazelon drew a variety of intriguing people into his orbit and engaged them immediately in the opposite of small talk.

We would sit at the round table in the Judge's office, munching on cookies and pretzels, while the Judge pressed a visitor for answers about the origins of crime, relationships between reason and emotion, or the political dimensions of ostensibly scientific evidence. In these sessions, Judge Bazelon manifested his enduring ambivalence about experts. On the one hand, he looked to them

† Professor of Law, Harvard University; A.B. 1975, University of Michigan; Ed.M. 1976, Harvard University; J.D. 1979, Yale University; Law Clerk to Judge David L. Bazelon, 1979-1980. The author thanks Katie Fallow, Erika George, Laurie Corzett, Mark Gould, Deborah Stone, and Barbara Woodhouse for their helpful comments and Rick Weissbourd, Joe Singer, and Vicky Spelman for their valuable conversations about the issues. This Article also reflects the author's participation in the American Academy of Arts and Sciences Initiatives for Children project on home visiting, although the views expressed are solely those of the author. 
for advice, insight, and answers; on the other hand, he brought a skepticism to the table that escalated with any expert's use of jargon or claim that the public could not understand. It is this ambivalence toward or dual approach to social science expertise that I will explore in this essay by asking: "What does social science offer policy-making-and vice versa?"

One additional theme from Judge Bazelon's work influences my choice of topics. Judge Bazelon persistently looked for the root causes behind a visible problem, whether the problem was the criminal offense of an impoverished defendant or the recalcitrance of a public bureaucracy. Opportunities for children lay close to his heart as he probed for causes and solutions. How could society alter the disadvantages of poverty, social isolation, or violence so that every child would have a fair chance? In the absence of that fair chance, Judge Bazelon believed that the criminal justice system must acknowledge the actual contexts of defendants' lives. More fundamentally, Judge Bazelon believed that the courts could never rectify the deep injustices in a society that assigns different opportunities to different kinds of children. In search of policies to rectify injustices of this nature, my tribute to the Judge addresses early childhood programs. As I turn now to home visiting social support programs, I hope to carry on Judge Bazelon's commitment to contextual justice along with his ambivalence about social science.

\section{Home Visiting: Social ScIence Evidence}

\section{AND PUBLIC POLICIES}

Can deliberate efforts to help disadvantaged children work? Debates over this question engage large issues about evaluation methods or, more basically, the nature of knowledge about a messy world. How would we define what it would mean for a program to work? How can we disentangle factors in people's lives that predate the social intervention and coexist along with it? Before getting lost in these issues, let's look at a social intervention that seems to work.

In my conversations with social service providers, policy analysts, and physicians about the needs of families, the phrase "home visiting" recurs. Encompassing a potentially broad spectrum of possibilities, home visiting typically refers to programs that equip individual "visitors" with information about pregnancy, infant needs, child development, nutrition, and parenting tasks, and help them to develop relationships with pregnant women or new parents through 
regular visits in the home. ${ }^{1}$ Some of the programs tie directly to health care centers; others have referral arrangements with health and human services programs. ${ }^{2}$ Some programs use professionals as visitors, others use lay people typically drawn from the community itself. ${ }^{3}$ The benefits of these programs to infants and to parents can include support and friendship during stressful periods ${ }^{4}$ and, perhaps more impressively, enhanced health and development for children and greater self-worth, self-reliance, and career development for their parents. ${ }^{5}$

Especially intriguing to me is the intensity of high-quality evaluations of home visiting programs. Dr. David Olds and his colleagues, for example, have conducted family support programs with teenage mothers who face real risks of poverty, poor health for themselves and their children, and child abuse and neglect. ${ }^{6}$ Dr. Olds combined these programs with sophisticated research designs,

${ }^{I}$ See BARBara H. WASIK ET AL., HOME Visiting: Procedures for HELPING FAMILIES 13 (1990) (discussing the functions of home visiting).

${ }^{2} \mathrm{See} i d$. at $69-90$ (discussing a variety of home visiting programs in diverse locations, including those with state, federal, and private funding, programs employing paraprofessionals, and programs illustrating restrictive inclusion criteria). One study reports that "[s]eventy-three percent of the programs were freestanding, and not combined with other types of programs, although most voluntarily coordinated their services with other programs. ... Thirty-nine percent of the programs were educational, $36 \%$ were health-related, $23 \%$ were viewed from a social services perspective, and $2 \%$ were Head Start programs." Douglas R. Powell, Inside Home Visiting Programs, FuTURE OF CHILDREN, Winter 1993, at 23, 25.

3 See WASIK ET AL., supra note 1 , at 69-90.

${ }^{4}$ See id. at 228-29.

${ }^{5}$ See Deanna S. Gomby et al., Home Visiting: Analysis and Recommendations, FUTURE OF CHILDREN, Winter 1993, at 6, 10-12.

${ }^{6}$ See David L. Olds et al., Improving the Delivery of Prenatal Care and Outcomes of Pregnancy: A Randomized Trial of Nurse Home Visitation, 77 PEdiatRIcs 16, 16-28 (1986) (evaluating the effects of a comprehensive program of prenatal and postpartum nurse home visitation, as compared with women randomly assigned to comparison groups); David L. Olds et al., Preventing Child Abuse and Neglect: A Randomized Trial of Nurse Home Visitation, 78 PEDIATRICs 65, 65-78 (1986) (testing home visitation by nurses as a method of improving the health and development of children born to women who were either teenagers, unmarried, or of low socioeconomic status); see also David L. Olds, The Prenatal/Early Infancy Project, in FouRTEEN Ounces of Prevention: A Casebook for Practitioners 9, 9-23 (Richard H. Price et al. eds., 1988) (analyzing the effectiveness of a program of nurse home visitation in preventing both maternal and child health problems associated with poverty); David L. Olds \& Harriet Kitzman, Can Home Visitation Improve the Health of Women and Children at Environmental Risk?, 86 PEDIATRICS 108, 108-16 (1990) (reviewing randomized trials of prenatal and infancy home visitation programs and concluding that the more effective programs utilized nurses who began visiting during pregnancy, visited frequently, and addressed the psychosocial factors that influence maternal and child outcomes). 
including random assignment, and numbers large enough to achieve statistical significance. His results thus meet the demands for rigor devised by social scientists themselves. ${ }^{7}$ His studies have compared the use of a home health visitor who met with young women from pregnancy until the child reached age two with interventions providing free transportation to health clinics for prenatal and wellbaby care and diagnostic testing of the infants.

These studies concluded that the women who were visited by a nurse during pregnancy participated more frequently in childbirth classes, showed greater improvements in their diets, and were more likely to find a supporting person to accompany them during labor. ${ }^{8}$ Those who received visits after the child's birth had fewer emergency room visits with their infants, and their children had fewer accidents and ingestions of dangerous substances than did those of the mothers who had no such visits. ${ }^{9}$ Dramatic reductions in state-verified child abuse cases were also associated with home visits. ${ }^{10}$ Home visits also reduced subsequent pregnancies and the costs associated with them, notably varied forms of public assistance. ${ }^{11}$ Another study of similar home visiting programs for mothers who are depressed yielded this interesting result: while the mothers' depression did not change, their children showed enhanced cognitive and emotional development, compared with children of other depressed mothers who did not receive such visits. ${ }^{12}$

These are only a few among dozens of studies. The U.S. General Accounting Office has issued two recent reports examining home visiting. ${ }^{13}$ The Packard Foundation's journal, The Future of Children, devotes an entire recent issue to home visiting and

${ }^{7}$ See Victoria Seitz, Outcome Evaluation of Family Support Programs: Research Design Alternatives to True Experiments, in AMERICA's FAMILy SuPPORT PROGRAMS 329, 332-34 (Sharon L. Kagan et al. eds., 1987) (offering the Olds study as an example of effective use of random assignment to yield interpretable data).

${ }^{8}$ See David L. OIds et al., Effect of Prenatal and Infancy Nurse Home Visitation on Government Spending, 31 MED. CARE 155, 156 (1993).

${ }^{9}$ See id.

${ }^{10}$ See id.

1 See id. at 162-63.

12 See Karlen Lyons-Ruth et al., Infants at Social Risk: Maternal Depression and Family Support Services as Mediators of Infant Development and Security of Attachment, 61 CHILD DEv. 85, 93-95 (1990).

${ }^{13}$ See U.S. GeN. ACCT. OFF., PUB. No. GAO/HRD-92-99, ChILd ABuse: PreVENTION Programs NeEd Greater EMPHASIS (1992); U.S. GEN. ACCT. OfF., PUB. NO. GAO/HRD-90-83, HOME VISITING: A PROMISING EARLY INTERVENTION STRATEGY FOR AT-RISK FAMILIES (1990). 
includes careful evaluations of the existing knowledge base by cautious social scientists. The summary of these evaluations frames its conclusions with caveats about the lack of high-quality studies comparing various intervention models and the absence of sufficient replications to permit generalized findings about different populations-a gap prompting the summary to call for more studies. ${ }^{14}$ Nonetheless, the summary concludes that "[e]vidence for the effectiveness of home visiting programs is as good or better than the evidence for the effectiveness of many other programs that exist to serve children and families." ${ }^{15}$ The summary recommends extension of services like home visiting to every community, because of the positive results emerging from programs that send visitors trained to provide information about health and parenting to the homes of pregnant women and families with pre-school children. ${ }^{16}$ The summary concludes that home visiting programs lead to improvements in some children's physical health, cognitive ability, and motor development, and to better parent-child interactions and reduced use of emergency hospital services. ${ }^{17}$ All of these results are consistent with a conclusion of lowered child abuse or neglect.

The federal government has registered some level of interest in home visiting: several existing programs, including Head Start, authorize home visits, ${ }^{18}$ and several pending pieces of legislation would also support them. National commissions and advisory boards endorse home visiting. ${ }^{19}$ Two states have adopted state-wide home visiting programs. ${ }^{20}$ Foundations have funded both research and demonstration projects involving home visits. Other private groups currently treat home visiting as a topic worth advocating in the public sphere. ${ }^{21}$ Yet I think it is still fair to say that home

${ }^{14}$ See Gomby et al., supra note 5, at 9, 18. The authors of this important and useful article kindly asked for my comments on a draft and more generally have instructed me about research in the field. No comments in the text should be read as critical of this article; my concern relates to the more general trend of distance between research and policy practices.

${ }^{15}$ Id. at 19.

${ }^{16}$ See id. (stating that home visiting could benefit all communities).

${ }^{17}$ See id. at 10-11.

${ }^{18}$ See FUTURE OF CHILDREN, Winter 1993, app. at 212-14 [hereinafter Appendix] (describing several "major federal initiatives" featuring home visiting).

${ }^{19}$ See Olds et al., supra note 8 , at $166,167 \mathrm{nn} .2$ \& 4 (noting support of home visitation programs by the National Commission to Prevent Infant Mortality and the U.S. Advisory Board on Child Abuse and Neglect).

${ }^{20}$ See Gomby et al., supra note 5, at 6-7 (noting that Hawaii and Missouri have such programs).

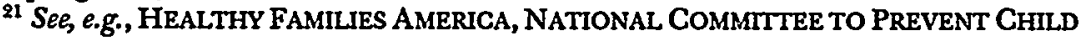


visiting is far from a household phrase, much less a prevalent practice in the United States, despite demonstrations by social science studies of its apparent effectiveness.

If there is as good or better evidence of the effectiveness of home visiting as there is of existing services, why don't more communities adopt such programs? The evidence supports three kinds of reasons for this failure. First, social scientists and policy makers inhabit different and apparently disconnected worlds in terms of approaches to knowledge. Second, home visiting programs fall prey to predictable policy cycles, dismantling social innovations in the absence of broad constituencies to support the programs. Third, cultural and historical experiences lead many to perceive home visiting as intrusive, insensitive, controlling, and bureaucratic-even though these perceptions remain largely absent from social science evaluations of the programs. I explore these three reasons in turn in the hope that this discussion will trigger a broader investigation into the relationship between social science and policy.

\section{A. Two Worlds}

Why does social scientific evidence of effective programs fail to produce policies that support home visiting programs? ${ }^{22}$ One reason may be that social scientists and policy-makers work in two worlds, with two different vocabularies and sets of concerns. More precisely, and curiously, the very cautiousness of social science undermines its usefulness in policymaking. In order to meet their own standards of accuracy and fairness, social scientists are reluctant to trumpet home visiting. For example, a prominent review of existing evaluations (known in the trade as a "metaevaluation"), published in the Packard Foundation journal, The Future of Children, rejects as untrustworthy studies of home visiting that fail to use randomized assignment of women and children to home visiting and to "control" programs that do not use home

Abuse, Rationale for a Statewide healthy Families America EfFort (1994); MASSACHUSETTS CHILDREN'S TRUST FUND, A REPORT ON NEWBORN HOME VISITING PROGRAMS IN MASSACHUSETTS (1993) (advocating universal newborn visits). See generally Heather B. Weiss, Home Visits: Necessary But Not Sufficient, FUTURE OF CHILDREN, Winter 1993, at 113, 118 (describing the growth of home visiting programs and the national policy statements recommending them).

${ }^{22}$ Let me be clear here that by policymaking, I mean to include not only public policies set by federal, state, and local governments, but also private policies set by nonprofit groups, including foundations, community organizations, and religiouslyaffiliated agencies. 
visits. ${ }^{23}$ This excludes from consideration all quasi-experimental studies that compare information about visited families before and after the visits and those studies that compare information about visited families with families who did not receive the visit due to "natural" reasons rather than random assignment. ${ }^{24}$ Clinical observational studies made by participants without the rigors of the scientific method are also excluded. ${ }^{25}$ The general result of such meta-analyses is to limit what counts as reliable knowledge to relatively expensive and cumbersome studies. The practical result, in the area of home visiting, has been the neglect of some of the programs that have generated the most enthusiasm about home visiting. ${ }^{26}$

The Packard Foundation meta-evaluation, therefore, whittles down the available research to the thirty-one "high-quality" random assignment studies. Moreover, general enthusiasm for home visiting is greatly mitigated through this kind of meta-evaluation because the programs under review and the populations they serve vary considerably, hampering the ability of researchers to generalize across them. ${ }^{27}$ Finally, as the Packard Foundation report indicates, careful analysis tends to show how little rather than how much we know. ${ }^{28}$ The report identifies, for example, the following complications: (1) most studies lack adequate causal models to identify the relationships between individual behavior and social context that affect adverse behaviors (such as cigarette smoking, alcohol consumption, and illegal drug use) and that the home visitors seek

${ }^{23}$ David L. Olds \& Harriet Kitzman, Review of Research on Home Visiting for Pregnant Women and Parents of Young Children, FUTURE OF CHILDRE, Winter 1993, at 53, 54-55.

24 See Gomby et al., supra note 5 , at 9.

${ }^{25}$ Cf. PAul E. Meehl, Clinical Versus Statistical, Prediction: A Theoretical ANALYSIS AND A REVIEW OF THE EVIDENCE (1954) (comparing clinical and statistical judgment).

${ }^{26}$ See Gomby et al., supra note 5, at 9 (stating that popular programs producing tremendous excitement "cannot provide evidence of the effectiveness of home visiting which is as persuasive as that provided by true experimental studies").

${ }^{27}$ See Olds \& Kitzman, supra note 23, at 56 (asserting that "results [of studies] can properly be generalized only to populations similar to those who participated in the studies"); see also Weiss, supra note 21, at 119 (noting the difficulty in generalizing across "high-quality studies" because they have not "tested the same intervention models").

${ }^{28}$ Cf. Charles E. Lindblom \& David K. Cohen, Useable KnOwledge: Social SCIENCE AND SOCIAL PROBLEM SOlviNg 1-29 (1977) (suggesting methods that social scientists should use to understand their work both as a possible contribution to policymaking as well as to other forms of social problem solving). 
to affect; ${ }^{29}$ (2) none of the studies look at the programs' influence on women's compliance with doctors' medication prescriptions or orders to reduce practices that risk transmitting sexual diseases; ${ }^{30}$ (3) measuring reductions in child abuse and neglect is difficult because there are no standard measures of maltreatment and instead the studies rely upon official records; ${ }^{31}$ and (4) the comparisons between control groups and experimental groups can be undermined by attrition or by important differences between the groups from the start. ${ }^{32}$ Furthermore, the variance between ideal home visits and what happens in practice is itself little studied, making it almost impossible to distinguish between program design and implementation when attempting to locate the shortfalls in effectiveness. ${ }^{33}$

Yet even in the face of these complications and qualifications, the authors of the meta-analysis conclude that "[h]ome visiting programs for parents of preterm and low birth weight newborns have been remarkably successful in promoting qualities of prenatal caregiving and children's intellectual functioning. ${ }^{34}$ They also found that two multi-problem, comprehensive programs helped to reduce reported child abuse and neglect. ${ }^{35}$ The study reports less conclusive and less impressive conclusions about the uses of home visiting to prevent preterm delivery and low birth weight, or to benefit socially and economically disadvantaged families generally. $^{36}$

${ }^{29}$ See Olds \& Kitzman, supra note 23 , at 57 (stating that " $[t]$ he failure of most trials is . . . largely a reflection of inadequate causal models underlying the program design and a failure to concentrate the services on women with specific risks that are amenable to change").

${ }^{30}$ See id. at 62 (noting that studies have failed to examine the programs' effect on at least two aspects of women's health-related behavior-the taking of prescription medication and the use of precautions to avoid the spread of sexually transmitted diseases).

${ }^{31}$ See id. at 80 (arguing that it is difficult to determine the programs' effect on the reduction of child abuse and neglect because there are no standards to aid in the comparison of data).

${ }^{32}$ See id. at 69 (noting the manner in which attrition and different group characteristics such as income levels, marital status, and race compromise trial results).

${ }^{33} C f$. id. at 85 (explaining how research designs, methods and program models have only begun to tap the potential of home visiting programs).

${ }^{34} I d$. at 86.

${ }^{35}$ See id. at 88 (recognizing that " [t] he two [child abuse] programs that showed the greatest promise used multiproblem, comprehensive approaches to serving families").

${ }^{36}$ See id. at 86-87 (noting that programs for parents of preterm and low birth weight babies vary in their effectiveness); see also id. at 87 (noting that "[ $t$ ] he evidence 
A more optimistic report, by Heather Weiss, director of the Harvard Family Research Project, looks at the same evidence and concludes that "most of the demonstrably effective family-focused early intervention programs include frequent (once a month or more) home visits as a core service" and find this service associated with "positive health and/or developmental outcomes for children" and higher self-esteem and continuing education for mothers. ${ }^{37}$ Yet even this optimistic analysis is carefully framed by the limitations of the data and the existing studies. ${ }^{38}$ Weiss concludes with a call for even more ambitious services and collaboration efforts to produce comprehensive and coordinated programs. ${ }^{39}$ In sum, while some scholars emphasize the strengths, and others stress weaknesses of the existing data, all tend to see complications.

Most policy-makers do not like complications. Nor do they like to read fine print. If they do, qualifications and cautions of the kind described here elicit skittishness. If we cautiously consider that home visiting helps some people, some of the time, and in some respects, we have failed to articulate the kind of powerful finding that can motivate action by public or private entities. Perhaps this is merely a public relations problem. It seems likely, however, that what counts as rigor in the social sciences risks undermining the confidence crucial to the policy realm.

The misconnection between social science and policy also has a source on the policy side. The policy process, especially in government settings, seems often to demand slogans and simplification; a related problem seems to be a high intolerance for risk and uncertainty. As a result, two very predictable patterns can ensue-either inaction in the policy realm in the face of apparent complexity in the research, or excessive promises unwarranted by the evidence, which are likely to lead to deflation, disappointment, and, ultimately, to divestment when the program does not solve all problems. ${ }^{40}$ The second pattern may well describe early childhood

regarding program effectiveness for parents and children from socially and economically at-risk families is much less consistent").

${ }^{37}$ Weiss, supra note 21 , at 120 .

${ }^{38}$ See id. at 119.

${ }^{39}$ See id. at 124-25.

40 See Martha Minow, The Seventy-Six Trombones of Career Education 53-55 (Sept. 1977) (unpublished manuscript, on file with the author); see also id. at 55 (noting that "false expectations and the accompanying disillusionment" lead communities to abandon programs that may have some beneficial outcomes). 
programs that have undergone regular cycles of promotion and cutback in this country. ${ }^{41}$

Policy makers look for a kind of authority from social science to quell all questions and preclude continuing analysis. Here Judge Bazelon's ambivalence toward experts might prove instructive. For just as it is unwise to turn policy judgments over to experts, it is also unwise to expect them to resolve all kinds of questions and doubts. The experts have something but not everything to offer.

The thirst for certainty and the fear of risk in the policy world no doubt reflect the variety of factors affecting decisions that can for convenience be called "politics." Politics here includes the techniques it takes for a topic like "home visiting" to get on the agenda, the need to build a constituency for it, the danger that the very identity of those who support it may produce antagonists, and other familiar features of our collective lives. Several features of contemporary social science exacerbate the political difficulties for home visiting. Social scientists, due to their own specialized training, funding sources, or professional incentives, are preoccupied with sorting types of populations, types of programs, and types of effects. This mind set, and the limited conclusions it can produce, vitiates general pronouncements that tend to motivate policymaking. At the same time, social scientists studying home visiting have not mounted the case for the kind of subtle and supple policies that would recognize multiple populations and extend permission for local variety in programs. The research on home visiting in particular has yet to yield findings that help make this kind of case.

One specific reason for this stems from a bias against self-report data and other kinds of input from participants in the programs. This bias appears in social science research and in the demonstration and model home visiting programs that affected the development of subsequent policies. I first thought about this problem while reading a critique of studies about learned helplessness ${ }^{42}$ and the "battered woman's syndrome" among women who have been

${ }^{41}$ See Gilbert Y. Steiner, The Futiltty of Family Policy 89-128 (1981) (discussing the transient funding and promotion of early childhood programs).

42 For a discussion of learned helplessness, see Lenore E. Walker, Battered Women and Learmed Helplessness, 2 VICTIMOLOGY 525, 525 (1977) (exploring a "psychological rationale for why the battered woman becomes a victim, and how the process of victimization further entraps her, resulting in psychological paralysis to leave the relationship"). 
abused by their husbands or boyfriends. ${ }^{43}$ Professor Coughlin joins with other critics of the legal defense created to excuse battered women from responsibility for their acts; these critics fear that such an excuse perpetuates stereotypes about women's lesser competence and irrationality. Yet Coughlin goes further and suggests that the empirical studies proffered to support the legal defense are themselves infected with the negative assumptions about women. ${ }^{44}$ Just as the battered women's defense implies that women lack rationality, these studies proffered in support of it ignore women's own perspectives and self-understandings. ${ }^{45}$

A more modest critique along two similar lines can be articulated about the home visiting research. First, the research on home visiting basically neglects the self-understandings of the participants who receive home visits-and of those who do not. Indeed, the researchers almost entirely fail to ask people receiving visits-and those who do not-what they think their own needs are when it comes to prenatal and postnatal assistance, what they think their communities need, how they view home visits when they have them, and so forth. The research proceeds largely on the model of natural science, treating people who receive visits and people who give them as objects whose movements can be charted in the world, rather than as individuals with subjective interiors, wants, dislikes, and ambivalences. Such information would not only be crucial to understanding truly what makes home visits work when they do, but it may also be critical to developing a self-conscious consumer demand for home visits.

${ }^{13}$ See Anne M. Coughlin, Excusing Women, 82 CAL. L. REv. 1 (1994).

${ }^{44}$ See id. at 70-87.

${ }^{45}$ Coughlin offers an especially intriguing criticism of the use of learnedhelplessness models by the chief expert advocate of the battered women's defense, Lenore Walker. Coughlin explains that the psychological research underlying Walker's arguments looked at two groups of dogs that were placed in cages and exposed to electric shocks. The dogs in the first group had previously been exposed to shocks that they could not control, while the dogs in the second group had no prior exposure to shocks. The dogs in the first group remained in the cages and accepted the shocks, while the dogs in the second group quickly learned how to avoid the shocks entirely. See id. at 82-83. Walker leaves out descriptions of the second group, and Coughlin concludes that this produces her mistaken neglect of the ways in which women are never previously free from the cultural-not only psychologicalsources of their sense of powerlessness. See id. at 83-84. In addition, Coughlin notes that Walker then neglects the theoretical reformulation of the learned-helplessness hypothesis developed by Martin Seligman, the author of the dog studies; Seligman calls for a study of how people explain their own sense of helplessness to themselves as a critical dimension of learned helplessness in people. See id. at 84 . 
Secondly, the research presupposes that home visits are responsive to the needs of children in at-risk families, rather than imagining that they may be helpful to all families. This immediately identifies home visits as a program for social failures or deviants. ${ }^{46}$ As a sheer political matter, it is difficult to muster much support from people labeled that way, and it is also difficult to gain others' support for nonpunitive programs for people deemed by policy makers to be "social failures." This difficulty is linked to a second major reason evidence that home visits are effective may not yield policy successes, which I explore next.

\section{B. Policy Cycles}

Social science evidence of effective programs fails to produce policies to support those programs partly because evidence is only a small aspect of the policy process. Perhaps more important parts are historical, economic, and political contexts influencing reform cycles of hope and retrenchment cycles of disappointment. These cycles of reform and retrenchment, creating and then cutting back services for children and families, definitely characterize American history over the past century. ${ }^{47}$ Evaluators of demonstration programs promoting children's health and development funded by the Ford Foundation conclude that ${ }^{\text {a }}[\mathrm{t}]$ he history of intervention programs to enhance the health and child-rearing of disadvantaged families has been one of repetition-in one reform movement after another, similar goals, philosophies, even intervention strategies have been resurrected and tried again. ${ }^{48}$ Demonstration projects, even those that attain high public regard as successes, too often fail to secure permanent funding after the foundation money or start-up public funds run out. ${ }^{49}$ This is unfortunately a familiar pattern in

${ }^{46}$ It also neglects the historically shifting construction of the concept of a child "at risk." See generally CHILDREN AT RISK IN AMERICA: HISTORY, CONCEPTS, AND Public POLICY (Roberta Wollons ed., 1993) (surveying 20th-century public policy toward children at risk).

47 See generally RichaRd HOFstadter, THE AGE OF REFORM: From BRYAN TO F.D.R. (1955) (describing the complexities and eventual value of the Populist and Progressive movements); ARTHUR M. SCHLESINGER, JR., ThE CYCLES OF AMERICAN HISTORY (1986) (discussing the cyclical rhythms of American politics as well as the role and prospects of American government); ROBERT H. WIEBE, THE SEARCH FOR ORDER: 1877-1920 (1967) (describing the rise of a dynamic and optimistic middle class in the late 19 th century leading to the Progressive movement).

${ }^{48}$ Mary Larner et al., The Fair Start Story: An Overview, in FAIR START FOR CHILDREN: LESSONS LEARNED FROM SEVEN DEMONSTRATION PROJECTS 3, 19 (Mary Larner et al. eds., 1992) [hereinafter FAIR START].

${ }^{49}$ See Lisbeth Schorr, Keynote Address at the Rethinking Our Schools to Serve 
human services and in family support programs: short-term private money finances innovative efforts that then disappear because no long-term financing comes forward. Then another foundation or source of public dollars sponsors new innovations, and the cycle starts again.

Besides reflecting the lack of long-term financing, lack of memory, lack of attention, or simply cycles of reform that mirror the business cycle, ${ }^{49}$ policy cycles reveal the role of constituencies in the policy process. Obviously important in the adoption of public policies by local, state, and federal governments, constituencies, community agencies, and foundations in turn depend upon communities of interest, inside and outside their offices, in order to generate agendas, directions, and support for specific policies. Inattention to community and consumer preferences means inattention to constituency building. ${ }^{50}$ Building constituencies is important in the tactical sense of securing the clout and pressure necessary to sustain policies, but it is also crucial to a democracy if human services are ever to reflect the desires of those they are supposed to benefit.

Theda Skocpol analyzed policy cycles in the United States affecting initiatives to help the most disadvantaged and found that even programs gaining sufficient support for adoption fail if they do not generate and sustain a constituency in time for renewing the programs. ${ }^{51}$ This difficulty is compounded for programs that are targeted at the most needy, rather than being universally available.

Today's Children Conference, co-sponsored by the Harvard Law School Children \& Family Rights Project and the Harvard Forum on Law and Education (May 14, 1992) (audio tapes available from Sound on Site, Boston, MA) (noting that few of the successful programs described in her book Within Our Reach existed three years after the book's publication).

${ }^{19}$ Herbert Croly believed that the "social problem must . . . be solved afresh by almost every generation; and the one chance of progress depends both upon an invincible loyalty to a constructive social ideal and upon a correct understanding by the new generation of the actual experience of its predecessors." HERBERT CROLY, THE PROMISE OF AMERICAN LIFE 140 (Arthur M. Schlesinger, Jr. ed., Harvard Univ. Press 1965) (1911).

${ }^{50}$ See Robert Halpern, Issues of Program Design and Implementation, in FAIR START, supra note 47, at 179, 194-97 (discussing the importance of acknowledging broader community issues in providing effective aid to families).

${ }^{51}$ See Theda Skocpol, Targeting Wilhin Universalism: Politically Viable Policies to Combat Poverty in the United States, in THE URBAN UNDERCLASS 411, 415-20 (Christopher Jencks \& Paul E. Peterson eds., 1991) (discussing the harsh political realities that halted the efforts of important initiatives, such as poor houses in the 19th century, mother's pensions, and the War on Poverty). 
Those programs not only risk stigmatizing their participants, but they also fail to build the kinds of widespread support necessary for their continuation. Skocpol acknowledges that universally available services are more expensive precisely because they cover more people; nonetheless, these programs may be more easily sustained because they have people across income brackets, regions, and interest groups who invested in them. ${ }^{53}$ The contrast between programs targeted for poor populations in the United States and similar programs made universally available in Europe provides a rich context for reviewing the political vulnerability of the targeted programs and the relative strength of the universal ones. ${ }^{54}$

Home visiting presents an intriguing example for this analysis because it could so easily become a universal program. Home visiting programs could be made universally available to every pregnant woman or new mother, or they could be made universal by guaranteeing one home visit for each new parent and at the same time flexibly enabling access to further home visits or other services for those who need them. Programs with this structure have already been tried in some communities in this country ${ }^{55}$ and in other countries. ${ }^{56} \mathrm{My}$ point here is not so much to develop or advocate

${ }^{53}$ See id. at 414. As another commentator wrote:

Universal programs that provide benefits to all citizens, such as Social Security, are more expensive to maintain than means-tested programs, which target resources to impoverished populations. Means-tested programs are relatively efficient because they concentrate benefits and services on lowincome persons who most need them, but, as the proportion of meanstested programs in the portfolio of the programs of a welfare state increases, the political support for social spending may decline because middle-class citizens do not believe the programs to be relevant to themselves.

Bruce S. Jansson, The Reluctant Welfare State: A History of American SOCIAL WELFARE POLICIES 242 (1988).

${ }^{54}$ See, e.g., M. Manciaux et al., Child Health Care Policy and Delivery in France, 86 PEDIATRICs 1037, 1037 (1990) (describing the general success of maternal and child health care in France, where it is universally available).

${ }^{55}$ See Harvard Family Research Project, Pioneerinc States: InNovative FAMILY SUPPORT AND EDUCATION PROGRAMS-CONNECTICUT, KENTUCKY, MARYLAND, MINNESOTA, MISSOURI 16-20 (2d ed. 1992) (describing several programs involving home visits, including a voluntary program in Minnesota designed to enhance the competence of parents to provide the best possible environment for healthy growth of children from birth to kindergarten); Edward Zigler \& Heather Weiss, Family Support Systems: An Ecological Approach to Child Development, in CHILDREN, YOUTH, AND FAMILIES: THE ACTION-RESEARCH RELATIONSHIP 166, 189-94 (Robert N. Rapoport ed., 1985) (describing the Brookline Early Education Program).

${ }_{56}$ See, e.g., Sheila B. Kamerman \& Alfred J. Kahn, Home Health Visiting in Europe, FUTURE OF CHILDREN, Winter 1993, at 39 (describing universally available home 
a particular program design as to identify how the design itself may affect its political viability, whether delivered as a public or private service.

\section{G. Cultural and Historical Factors}

European countries have long provided home visits; unlike the models developing in the United States, the European model typically offers home visits to all families as part of prenatal and postnatal care. ${ }^{56}$ Research suggests that these widely accepted programs are also well-integrated into comprehensive systems of maternal and child health care, income maintenance, housing, and other governmental programs. ${ }^{57}$ To note such contrasting practices in other countries is to restate the basic question: Why doesn't evidence of the value of home visiting result in its adoption in this country?

Practices in other countries illuminate the significance of cultural traditions and assumptions to the present discussion. Certainly, social science evidence about programs in other countries, especially social welfare programs, does little to prompt adoption of similar programs in this country. If the current health care policy debate is any example, such comparative policy discussions essentially become grist for purely domestic political adversaries. Perhaps not much more needs to be said than to acknowledge that the United States has resisted state-sponsored health and social services except for the very disadvantaged, and a general opposition to state intervention in private life undergirds, or rationalizes, this cultural view. Moreover, several familiar features of the American scene pose obstacles to a policy like home visiting, including the following: distrust of the government, celebration of individual freedom and privacy, a laissez-faire economic policy coupled with similar hands-off approaches to social welfare, and disagreement about basic ways of life, including child rearing in a society composed of many cultures. ${ }^{58}$

health visiting services with a focus on the programs in Denmark and Great Britain).

${ }^{56}$ See $i d$. (stating that "[d]espite growing concern about limited resources to expend on social programs in many European countries, . . . home visiting programs continue to be universal").

${ }^{57}$ See id. at 41 (arguing that home visiting serves as a link between the family and a variety of social services or other governmental programs).

${ }^{58}$ See KATHLEen WOOdROOFE, From CharITY to SOCIAL WORK IN ENGLAND AND THE UNITED STATES 147 (1962) (noting that the welfare state did not develop in the United States as it had in England). Until 1937, when the Supreme Court upheld the 
These cultural values take on added weight given the fascinating history-and critique-of home visiting practices in the United States. Despite current presentations of home visiting as an innovation, elements of home visiting have existed in practice for over a century. Curiously, the contemporary social science literature is almost entirely silent about those earlier practices, except for an occasional remark upon the fact of their existence and disappearance. This ahistoricism in the social science world may be another defect affecting the policy world. It is not that policymaking is selfconscious about history, but it is more likely to operate in rooms constructed and renovated in earlier historical periods, with the legacies of earlier lights and shadows. Looking at the historical practices of, and responses to, early forms of home visiting, I suggest, would greatly assist our understanding of the contemporary failure to adopt it as a policy because the history reveals mixed, and even negative, responses.

Various versions of home visiting aimed at enhancing children's health and well-being have existed in the United States since the middle of the nineteenth century, ${ }^{59}$ or even earlier if visits sponsored by religious groups are included. ${ }^{60}$ Historians note that charitable organizations in both England and the United States sponsored home visits during periods of industrialization and urbanization. The upper-class leaders of the charitable efforts emphasized that home visiting could encourage individual responsibility among the poor and provide them with much-needed moral guidance from the privileged classes. ${ }^{61}$ The present resistance to home visiting, not mere indifference, may result from a contemporary disdain for the forerunners of home visiting, which came in the form of charity work by "friendly visitors" and "Lady Bountifuls" in the late nineteenth and early twentieth centuries.

Social Security Act as constitutionally valid, the judiciary opposed social services provided by the federal government. See id. at 174-75.

${ }^{59}$ See id. at $46-47$ (describing charitable organizations in England, which relied upon "friendly visitors" to gather important information from families applying for relief).

${ }^{60}$ See id. at 44 (discussing the work done by various religious organizations in the 17th century).

${ }^{61}$ See PaUl Boyer, URban Masses and Moral ORder In AMERICA, 1820-1920, at 159-61 (1978) (noting that even as charitable organizations became increasingly concerned with the impact of the environment surrounding poor families, they continued to hope that poor families would come to imitate their upper-and middleclass visitors and even adopt the visitors' value systems). 
The early English charitable organizations stressed the importance of private voluntary efforts rather than government intervention, ${ }^{62}$ and proceeded on the assumption that the existing economic and social structures were sound. ${ }^{63}$ In the United States, charitable societies trained volunteers, known as "friendly visitors," to investigate requests for assistance, to distinguish the deserving from the undeserving poor, and to provide a moral example. ${ }^{64}$

Mary Richmond, a leader in the American movement, organized charity organizations to pursue both social action and individual casework. ${ }^{65}$ Richmond produced an important book called Friendly Visiting Among the Poor ${ }^{66}$ and also the classic text on casework, which she entitled Social Diagnosis. ${ }^{67}$ In these works, Richmond explored how the charity worker could help effect an adjustment between the individual and the environment so that individuals could become productive participants in the larger society. Richmond pursued an intriguing conception of investigation and critical analysis that helped forge the foundations of professional social work, psychology, and, more generally, social science. ${ }^{68}$ At the same time, her work emphasized the significance of the relationship between the friendly visitor and the family as one of intimacy and sympathy-a relationship that would be a good in and of itself, beyond the diagnosis and advocacy the visitor would also pursue. ${ }^{69}$ Richmond also stressed that this relationship should be democratic, seeking mutual advantage through cooperation between visitor and client. ${ }^{70}$ Yet Richmond also maintained that poverty,

${ }^{62}$ See WOODROOFE, supra note 58, at 34 (noting that "it was both necessary and desirable that State intervention be kept to an absolute minimum").

${ }^{63}$ See id. (noting that charity workers assumed "that all was well with the economic and social organization of society").

G See Walter I. TRattNer, From POOR LAW to Welfare State: A History OF SOCIAL WELFARE IN AMERICA 87 (1974).

${ }^{65}$ See WOODROOFE, supra note 58, at 103.

${ }^{66}$ MARY E. RICHMOND, FRIENDLY VISITING AMONG THE POOR: A.HANDBOOK FOR CHARTY WORKERS (1899).

${ }^{67}$ MARY E. Richmond, SOClal Diagnosis (1917).

${ }^{68}$ See infra note 124 and accompanying text (discussing the numerous contributions Richmond and her colleagues made to the growth of American social science).

${ }^{69}$ See WOODROOFE, supra note 58, at 112 (" $[$ A] lthough little is said in Social Diagnosis about the client-worker relationship . . . it is obvious that Miss Richmond recognized the value of relationship as a medium through which aid to the client could be effected.").

${ }^{70}$ See id. at 115 (noting that Richmond was the first to introduce the concept that the process of social work could be a democratic one in which the caseworker and client cooperate to their mutual advantage). 
at its core, stemmed from defects in individual character, and that the sexual division of labor practiced by the middle class was a moral command for the poor as well. ${ }^{71}$

Similarly, Josephine Shaw Lowell, the New York Charity Organization leader, urged "friendly visitors" to resist the temptation to provide actual food and support to those in need and to avoid procuring temporary relief. Instead, the visitor was encouraged to help the poor start to find work and earn money, to avoid extravagance, shiftlessness, and vice, and never to teach or convey to them that they can receive something for nothing. ${ }^{72}$ In that age of unselfconsciousness about class privilege and bias, Lowell suggested that " $[t]$ he visitors might perhaps persuade their own servants to train a young girl to fit her to be a good servant and to earn good wages. ${ }^{\text {73 }}$

Notably, that lack of self-consciousness about class and power ended quickly. Jane Addams, known today for her leadership in the settlement-house movement, wrote her first book in 1902 as a critique of the home visiting practices of upper class charity organizations. Democracy and Social Ethics ${ }^{74}$ is in many ways a work of anthropology as well as a work of persuasive politics; in it, Addams portrays the perceptions of the home visitor who is appalled by the child-rearing, spending, and work habits of a poor family. ${ }^{75}$ Then, bit by bit, Addams reveals the contrasting assumptions and reasons for their actions from the perspective of the family. ${ }^{76}$ Rather than lazy and vicious, the family, according to Addams, should be understood as having different values and practices-and the charitable visitor should be understood as deeply mistaken at best, and unfeelingly oppressive at worst. ${ }^{77}$ Although the charity worker may find the mother hasty and rude to the children, the mother may view her actions as crucial to developing the children's appreciation of the social conventions that will govern

\footnotetext{
${ }^{71}$ See BOYER, supra note 61, at 160 (discussing Richmond's Friendly Visiting Among the Poor).

${ }^{72}$ See Josephine S. Lowell, Duties of Friendly Visitors, in THE PHILANTHROPIC WORK OF JOSPHINE SHAW LOWELL 142 (William R. Stewart ed., 1911) (establishing guidelines for "friendly visitors").

${ }^{73} I d$. at 148.

74 JANE AdDAMS, Democracy AND SOCIAL ETHics (1902).

${ }^{73}$ See id. at $32-45$.

${ }^{76}$ See id.

77 See THE Social Thought OF JANE ADdAMs 62-63 (Christopher Lasch ed., 1965); see also ADDAMS, supra note 74, at 23-24 (describing the different perceptions held by the charity visitor and the poor person).
} 
their lives. ${ }^{78}$ The charity worker may be appalled at the proportion of her income the mother spends on her clothes, without realizing how critical clothing will be to the woman's social and economic advancement. ${ }^{79}$ Addams used such observations to illustrate how not only the visited family, but also the charitable worker, belong to particular cultures that carry with them distinctive values and coping practices. Addams believed that recognizing the practices of the poor as valid cultural differences would force the "home visitors" to stop presuming that the poor were simply inferior and in need of correction. Indeed, Addams hoped that looking at the world from the perspective of immigrants and poor people would produce humility in anyone who presumed to try to help them. ${ }^{80}$

This attitude of humility and mutual respect pervaded the settlement-house movement, which opposed charity and proposed instead to engage in social and political reform as a member of the poor neighborhood. ${ }^{81}$ Under the movement's philosophy, the person of privilege should become an actual neighbor, not a periodic visitor, to the poor; the strengths as well as the weaknesses of the poor should be recognized. Similarly, the unit of analysis in dealing with poverty should be the neighborhood, political ward, or industry, not merely the individual. ${ }^{82}$

Addams and her colleagues, however, have themselves been criticized for maintaining middle-class, Victorian values and stan-

${ }^{78}$ See ADDAMS, supra note 74, at $32-33$ (describing attitudes among the poor concerning child rearing). For discussions about contrasting child-rearing practices reflecting cultural and religious differences, see PHILIP GREVEN, THE PROTESTANT TEMPERAMENT: PATTERNS OF CHILD-REARING, RELIGIOUS EXPERIENCE, AND THE SELF IN EARLY AMERICA (1977); JEROME KAGAN, THE NATURE OF THE CHILD 240-76 (1984).

${ }^{79}$ See ADDAMS, supra note 74, at 34-36 (noting the importance of proper appearances with regard to advancement).

${ }_{80}$ See id. at 66-70. Practicing some of what she preached, Addams in this passage quotes a Hebrew prophet-appropriate, given the number of Jewish families subjected to the charitable visits under study. In her settlement-house initiative, Addams insisted upon moving into the neighborhood and becoming part of the community of the poor rather than making friendly visits. See JANE ADDAMS, TWENTY YEARS AT HulL-House 125-27 (MacMillan Co. 1967) (1910).

${ }^{81}$ See Jane Addams, President's Address: Charity and Social Justice (May 19, 1910), reprinted in Procendincs of THE NATIONAL CONFERENCE OF CHARTTIES AND CORRECTION, at 1 (Alexander Johnson ed., Archer Printing 1910); DANIEL LEVINE, JANE ADDAMS AND THE LIBERAL TRADITION 126, $136-37$ (1971); see also LELA B. COSTIN, TWo Sisters FOR SOCIAL JUSTICE: A BIOGRAPHY OF GRACE AND EDITH ABBOTT 34-36 (1983) (tracing an American woman's contact with the English settlement movement); WOODROOFE, supra note 58, at 64-65 (discussing English origins of the settlement-house movement).

${ }_{82}^{82 e}$ BOYER, supra note 61 , at 157. 
dards. ${ }^{83}$ The distinction between the deserving and undeserving poor that animated the charitable visitors also permeates Addams's work, although she may have drawn the line in a different place. Although Addams criticized the charitable workers for maintaining that poverty is the fault of individual poor people, ${ }^{84}$ she also assumed that saloons, dance halls, and street life produced a lowerclass environment that should be replaced by a middle-class or upper-class milieu. ${ }^{85}$ Moreover, Addams and her colleagues proceeded on the assumption that immigrants should assimilate to dominant American culture. Only gradually did they learn about the intrinsic value of ethnic identities and practices. ${ }^{86}$

Despite rhetoric about social cooperation and mutuality, the settlement-house leaders "seldom doubted that they knew the correct solution to many of the immigrants' problems. ${ }^{387}$ Similarly, Addams's friends and intellectual companions, John Dewey and George Herbert Mead, devised philosophies about human selfactivity and democratic communion, despite qualifying and limiting

${ }^{83}$ See Rivka S. LISSAK, Pluralism \& Progressives: HUll House and the New IMMIGRANTS, 1890-1919, at 182 (1989) (arguing that Jane Addams and other Hull House leaders favored assimilating new immigrants rather than respecting their cultural differences, until they came to recognize the persistence of ethnic identity); see also Hilda S. POLACHECK, I CAME A STRANGer: THE STORY OF A Hull-House GIRL 118-26 (Dena J. Polacheck Epstein ed., 1989) (recounting perceptions of Jane Addams as someone who wanted to be helpful but did not fully understand immigrant customs, and who maintained tight control over activities for the immigrants).

${ }^{84}$ See ADDAMS, supra note 74, at 14-16. Note that in contrast to the stance of the charity workers, Addams joined in labor strikes in solidarity with her neighbors. See andrew Feffer, The Chicago Pragmatists and American Progressivism 110 (1993).

${ }^{85}$ See Allen F. Davis, Introduction to JANE ADDAMS, THE SPIRTT OF YOUTH AND THE CTTY STREETS at vii, xxvi-xxvii (Univ. of Ill. Press 1972) (1909); see also BOYER, supra note 61 , at 156 .

${ }^{86}$ See LISSAK, supra note 83 , at 182 . This may be too harsh a critique because the story Lissak traces actually depicts a remarkable openness to learning and change in attitude. See $i d$. at 184 (noting that the "concept of humanitarian social democracy and the[] benign policies of assimilation created a dynamic that unintentionally paved the way for a more pluralist view of society"); see also ROBERT M. CRUNDEN, MINISTERS OF REForm: The Progressives' ACHIEvement in AMERICAN Civilization, 1889-1920, at 66 (1982) (describing how Addams learned from experience that she should not have "definite rules and regulations" for responding to the employment issues of the poor neighbors, but instead should learn about their lives and "habits as a whole"). There is a practical danger that arises from an overly critical stance toward reformers and activists; it contributes to the hesitancy and caution that undermine action altogether.

${ }^{87}$ CosTIN, supra note 81 , at 71 (referring to Grace and Edith Abbott, and Sophonisba Breckinridge). 
democracy by simply calling for mutual aid and social cooperation, and for the most part neglecting deep social conflicts. ${ }^{88}$

Historian Paul Boyer suggests that the criticism of the charity workers by the settlement-house workers "flowed in both directions" and should be understood as mutual and also as something of a family quarrel, given the profound similarities between the two groups. ${ }^{89}$ The settlement-house workers not only joined the charity visitors in perpetuating their middle-class standards and judging working-class people in that light, ${ }^{90}$ but they also strengthened their attention to community problems such as exploitive labor practices. $^{91}$ Additionally, both shared a vulnerability to future criticism that social control was as much a goal of these groups as social and individual change. ${ }^{92}$

Critics writing in the 1960s in particular challenged many of the social reforms developed by Addams and other progressives as new efforts to control the poor. ${ }^{93}$ Emphasizing that the significance of class conflict and social structures of inequality could never be redressed by focusing on individuals in need, these critics demanded revisions of the larger economic and social order. ${ }^{94}$ Moreover,

${ }^{88}$ See FEFFER, supra note 84, at 252-53, 266-68.

${ }^{89}$ BOYER, supra note 61 , at 156 .

${ }^{90}$ See id.

91 See id. at 158; see also TRATTNER, supra note 64, at 91 (noting that charity organizers eventually began "to regard the social and economic causes of poverty as more pressing than personal inadequacy").

92 See BOYER, supra note 61, at 156-57. It is important to note the nuances here; there is a difference between an assimilative approach, treating those who violated the prevailing norms as misguided wanderers who can be persuaded to conform, and a commitment to coercive reforms, such as Prohibition, and the antiprostitution movement, which used criminal sanctions to force conformity. See JOSEPH R. GuSFIELd, SYMbOLIC CRUSADE: STATUS POLITICS AND THE AMERICAN TEMPERANCE MOVEMENT 69-86 (1963) (illustrating the distinction between assimilative reform and coercive reform in the Temperance movement).

${ }^{93}$ See, e.g., Frances F. PIVEN \& Richard A. Cloward, Regulating the PoOR: THE FUNCTIONS OF PUBLIC WELFARE 263-79 (1971) (interpreting 1960s programs as federal efforts to displace the state, local, and private authorities historically in charge of the poor).

Mr Michael Harrington's The Other America is commonly credited with framing national attention to the structural problems in the society that perpetuated poverty amidst a period of affluence. Within a short period of time, liberal and conservative political leaders and theorists took for granted the idea that poverty reflects a societal defect in need of change, rather than individual or exceptional failures. See MICHAEL HARRINGTON, THE OTHER AMERICA: POVERTY IN THE UNITED STATES (1962); see also MILTON FRIEDMAN, CAPITAIISM AND FREEDOM 174-75 (1962) (arguing that the gradual tax system will not work to redistribute wealth and recommending a flat-rate income tax); HUBERT H. HUMPHREY, WAR ON POVERTY 21-25 (1964) (describing the plight of 
against the backdrop of ethnic and racial pride strengthened by the civil rights movement, the press toward assimilation and "Americanization" by turn-of-the-century friendly visitors and settlement-house workers appeared controlling, condescending, and even oppressive. ${ }^{95}$

In contrast to their predecessors, the social welfare reforms of the 1960s emphasized community control and empowerment. For instance, community action programs, created with federal monies, coordinated local programs in poor communities. ${ }^{96}$ The authorizing federal legislation called for the "maximum feasible participation" of the poor in the boards governing these centers. ${ }^{97}$ The community action programs received some of the credit for the popular and successful Head Start program. ${ }^{98}$ Head Start specifically created roles for parent participation in governance and in dayto-day operations of the program. Head Start also called for home visits to reach out to parents of the young children enrolled in the program, but such visits have never been a major element of that program. ${ }^{99}$ Nonetheless, Head Start staff is composed largely of

the poor in the United States); Charles A. Reich, Individual Rights and Social Welfare: The Emerging Legal Issues, 74 YALE L.J. 1245 (1965) (surveying the legal issues surrounding welfare recipients). See generally MICHAEL KATZ, IN THE SHADOW OF THE POORHOUSE: A SOCIAL HISTORY OF WELFARE IN AMERICA (1986); Peter B. Edelman, Towards a Comprehensive Antipoverty Strategy: Getting Beyond the Silver Bullet, 81 GEO. L.J. 1697 (1993) (discussing poverty law and policy and arguing that the reduction of poverty will come only through a broader array of strategies and techniques).

${ }^{95}$ See KATZ, supra note 94 , at 76 (describing the ways in which the relationship between visitor and family was coercive in nature and stating that, "[i]n truth, the visitor was to be at once a sympathetic friend, an official, a teacher, and a spy").

${ }^{96}$ See DANIEL P. MOYNIHAN, MAXIMUM FEASIBLE MISUNDERSTANDING: COMMUNITY ACTION IN THE WAR ON POVERTY 79-100 (1969) (describing the efforts in Congress to provide comprehensive programs of community action).

${ }_{97} I d$. at $87-88$.

${ }^{98}$ Entire books address Head Start and the social science debates over its effectiveness. See, e.g., John R. Berrueta-Clement et Al., Changed LIVEs: The EfFects of the Perry Preschool Program on Youths Through Age 19 (1984); EdWARD ZIGLER \& SUSAN MUENCHOW, HEAD START: THE INSIDE STORY OF AMERICA'S MOST SUCCESSFUL EDUCATIONAL EXPERIMENT (1992).

${ }^{99}$ Head Start calls for at least two home visits for every participating family, although there are no specifications of when the visits should occur or who should make them. See Appendix, supra note 18, at 213 (citing ZiglER, supra note 98, at 155). More explicit and crucial to the program is Head Start's plan for significant parental involvement in the governance and operations of the program. See Head Start Policy Manual: The Parents, 45 C.F.R. § 1304 app. B (1993); see also id. $\$ 1304.5-5$. For a thoughtful exploration of the benefits that parents receive from participating in Head Start, see generally Lucie White, On the Vision and Practice of Participation in Project Head Start, in LAW STORIES (Gary Bellow \& Martha Minow eds., forthcoming 1995). 
members of the local community, including parents. Parents who are visitors to other parents can mitigate to some extent the perception of such visits as intrusive and oppressive. In addition, the community context of Head Start provides an important model for building programs that both reach their goals and succeed politically, benefitting precisely the kinds of families that home visiting programs seek most to assist.

From the vantage point of the reforms of the 1960s and others since, the earlier home visiting programs appear to have been riddled with class and ethnic conflict and burdened by the visitors' social control motivations and by racial and cultural insensitivities. ${ }^{101}$ Arguably, visitors from a different class, ethnicity, race, or region than the families receiving the visits lacked understanding, empathy, and solidarity. Moreover, programs designed and operated outside the local communities deprived the members of those communities of the opportunity for self-governance and power. ${ }^{102}$ Imposing standards from other communities and depriving people of the chance to participate in designing ways to meet their own needs is a familiar story about social welfare programs in this country, ranging from income supports to drug treatment programs. ${ }^{103}$ Home visiting programs, to many, exemplify these defects.

Those voicing such criticisms may well have misunderstood some of the commitments to community building developed by the settlement-house workers. ${ }^{104}$ Surely, to the extent that the con-

101 See Carmen G. Olivero, Study of the InItial Involvement in the Social Services By the Puerto Rican Migrants in Philadelphia 299-304 (1971) (reporting unresponsiveness of social services to Puerto Rican immigrants during the 1960s); $c f$. Diana T. Slaughter-Defoe, Home Visiting with Families in Poverty: Introducing the Concept of Culture, FUTURE OF CHILDREN, Winter 1993, at 172, 179-80 (noting that contemporary programs that have achieved success have given attention to the culture of the program staff). Social work texts now focus on the issues of ethnic and racial differences. See, e.g., PETER Ely \& DAVID DENNEY, SOCIAL WORK IN A MULTI-RACIAL SOCIETY (1987) (discussing problems encountered by people of different races, especially by Blacks, living in Great Britain); SHIRLEY JENKINS, THE ETHNIC DILEMMA IN SOCIAL SERvices (1981) (posing the questions of how, where, and when ethnic factors should be incorporated in service delivery).

${ }^{102}$ See generally KATZ, supra note 95, at 259-61 (discussing the government's recognition of the need for community action and the beneficial consequences of community action programs for America's war on poverty in the 1960s).

${ }^{103}$ See generally Iris M. Young, Punishment, Treatment, Empowerment: Three Approaches to Policy for Pregnant Addicts, FEMINIST STUdIEs (forthcoming 1994) (manuscript at 23, on file with author).

${ }^{10}$ See JANE AdDAMS, A CENTENNIAL ReAdER 16, 83-94, 190-217 (1960) (examining the settlement movement's commitments to democracy, social justice, and labor 
temporary call is for empowerment, it echoes the settlement-house movement's rhetoric of democracy. ${ }^{105}$ It may also neglect the ways in which community-based services risk corruption, patronage, and inefficiency. ${ }^{106}$ The critique also underestimates the serious invasions of privacy that can occur in a small community-where community-run services mean that a mother sees at the laundromat on Saturday or church on Sunday the woman who watched her fight with her child during a home visit on Friday. ${ }^{107}$ Nonetheless, these critiques of home visiting and traditional social services are powerful and may well contribute to contemporary resistance to home visiting programs. Furthermore, many policy makers in public and private settings today are the children and grandchildren of immigrants who experienced home visitors earlier in the century. Thus, the possibility of negative memory may be quite concrete.

A related historical and cultural value animates resistance to home visits. Concerns about liberty and privacy, couched in terms of constitutional or fundamental rights, often focus on the home as a sanctuary that should be free from scrutiny or intervention. Some judicial decisions support this view; others do not. ${ }^{108}$ Indeed, a

reform); ADDAMS, supra note 81, at 123, 179-80, 210 (discussing involvement in community interests and general awareness of Hull-House workers); ROBERT B. WESTBROOK, JOHN DEWEY AND AMERICAN DEMOCRACY 88-90, 93-111 (1991) (discussing Dewey's commitments to Hull-House and Jane Addams's ideas, to empowering poor and immigrant groups, and to reforming schools to advance individuality and democracy); see also LINDA GORDON, PITIED BUT NOT ENTITLED: SINGLE MOTHERS AND THE HISTORY OF WELFARE, 1890-1935, at 48-49 (1994) (stating that although Progressive era reformers were "self-righteous and culture bound," prominent ones were also "racial liberals" who believed that immigrants and African-Americans could become equal earners and participants in democracy).

${ }^{105}$ Compare Young, supra note 103, manuscript at 23 with ADDAMS, supra note 104, at 21-25.

${ }^{106}$ See supra note 105 and accompanying text; see also ALLEN J. MATUSOW, THE UNRAVELING OF AMERICA: A HISTORY OF LIBERALISM IN THE 1960s 217-71 (1984) (describing the widespread failure of President Johnson's War on Poverty and the particular problems faced by those charged with administering the Community Action Program).

${ }_{107}$ A research project currently underway suggests that many poor people oppose efforts to create tight, neighborhood-based networks for social support or other purposes and instead want access to a variety of communities. See Richard Weissbourd, Remarks at American Academy of Arts and Sciences Conference on Home Visiting (Oct. 19, 1993).

${ }^{108}$ Compare Stanley v. Georgia, 394 U.S. 557, 564-65 (1969) with Wyman v. James, 400 U.S. 309,317 (1971) (offering different opinions on the privacy rights afforded to one's dwelling). Sée also Bowers v. Hardwick, 478 U.S. 186, 195-96 (1986) (privacy rights do not protect against sodomy prosecution); California v. Carney, 471 U.S. 386, 390 (1985) (warrantless search of mobile home does not violate Fourth Amendment); 
continuing conflict between concerns about liberty and privacy, on the one hand, and safety and equality, on the other, characterizes legal and administrative regulation of child abuse, wife abuse, drug use, pornography consumption, and even television violence. ${ }^{109}$ Especially when someone who works for the government crosses the threshold of a private home, American legal and cultural values set off an alarm.

In such cases the exceptions may in fact spell out the rule. For example, the Supreme Court rejected a privacy claim brought by a recipient of Aid for Families with Dependent Children who objected to a home visit, reasoning that because the recipient risked only the loss of the public benefits, and no criminal penalty, that the Fourth Amendment privacy guarantees did not apply. ${ }^{110}$ In the absence of dependency on the state, those privacy concerns might well receive greater legal deference.

Home visiting under entirely private auspices might seem less invasive than government-sponsored programs. Yet the notoriously indeterminate distinction between public and private ${ }^{111}$ is especially

Payton v. New York, 445 U.S. 573, 576 (1980) (sanctity of the home requires higher governmental justification for surveillance).

${ }^{109}$ See John Gilliom, SuRveillaAnce, PRivacy, aNd the Law: Employee Drug TESTING AND THE POLITICS OF SOCIAL CONTROL 85-130 (1994) (examining privacy issues associated with drug testing, their constitutionality under the Fourth Amendment, and the counterbalancing concerns of society); CATHARINE A. MACKINNON, FEMINISM UNMODIFIED: DISCOURSES ON LIFE AND LAW 146-197, 215-228 (1987) (discussing pornography in terms of its effects on gender inequality and subordination, and its relationship to violent and sexual crimes); ELIZABETH PLECK, DOMESTIC TYRANNY: THE MAKINC OF SOCIAL POLICY AGainst Family VIOLENCE From Colonial Times to THE PRESENT 7-11 (1987) (discussing domestic privacy, conjugal and parental rights, and liberty within the family); Elizabeth $M$. Schneider, The Violence of Privacy, 23 CoNN. L. REv. 973, 977-79, 986-94 (1991) (addressing statutory reform in the area of abuse toward women and shifting views toward battered women).

${ }^{110}$ See Wyman, 400 U.S. at 317-18.

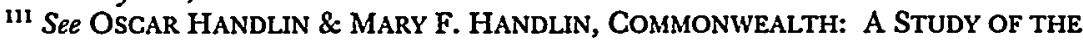
ROLE OF GOVERNMENT IN THE AMERICAN ECONOMY 149-72 (1947) (arguing that the contemporary public/private distinction did not exist in early-19th-century Massachusetts); HENDRIK HARTOG, PUBLIC PROPERTY AND PRIVATE POWER: THE CORPORATION OF THE CITY OF NEW YORK IN AMERICAN LAW, 1730-1870, at 158-75 (1983) (exploring historical development of public and private spheres in the planning of New York City); Carole Pateman, Feminist Critiques of the Public/Private Dichotomy, in The DISORDER OF WOMEN: DEMOCRACY, FEMINISM AND POLITICAL THEORY 118-40 (1989) (reviewing and critiquing feminist analyses of liberal political theory that attack the public/private distinction); Gerald E. Frug, The City as a Legal Concept, 93 HARV. L. REV. 1059, 1099-1109 (1980) (exploring instability of distinction between public and private in legal treatment of cities); Morton J. Horwitz, The History of the Public/Private Distinction, 130 U. PA. L. REV. 1423, 1428 (1982) (noting that the decline of the 
troubled in a world of complex contractual and financial relationships between public and private social services agencies. ${ }^{112}$ Moreover, when the home is the reference point for the private space, almost any visitor can be viewed as an outside intruder.

In addition, concerns about the home as a gendered space, occupied during the day by women and children, have animated arguments for privacy since Brandeis and Warren wrote their classic article. ${ }^{113}$ This gendered dimension of privacy associated with the home also supported regulations of commercial home visitors, such as encyclopedia salesmen. ${ }^{114}$

Liberty and privacy concerns, as well as efficiency and fairness arguments, also fuel critiques of both public and private human service programs as bureaucratic and uncoordinated. The charity

public/private distinction is linked to the end of decentralized competitive capitalism); Duncan Kennedy, The Stages of the Decline of the Public/Private Distinction, 130 U. PA. L. REv. 1349, 1351-54 (1982) (arguing that the categories of public and private become interchangeable and convergent); Frances $\mathrm{E}$. OIsen, The Family and the Market: A Study of Ideology and Legal Reform, 96 HARV. L. REv. 1497, 1499-1518 (1983) (exploring interrelationship of family and market spheres influencing the meaning of gender).

${ }^{112}$ Some argue that not-for-profit social agencies that work with the state increasingly become merely bureaucratic processing centers rather than independent providers. See Michael B. Fabricant \& STEVe BuRGhardT, The Welfare State CRISIS AND THE TRANSFORMATION OF SOCIAL SERVICE WORK 116-82 (1992)(discussing the transformation of not-for-profit social services agencies). Others note that the call for reprivatization of social welfare services neglects the fact that it was the failure of private agencies that led to the creation of the social welfare state. See PHYLLIS J. DAY, A NEW HISTORY OF SOCIAL WELFARE 388 (1989) (critiquing President Reagan's New Federalism).

This issue mirrors 19 th-century debates over whether to provide home visitors under governmental or private auspices. The charity organizations confronted arguments for tax-supported services. Mary Richmond favored private case-work, arguing that tax support benefits, "especially mothers' pensions, could not give the caring supervision that private social work practice provided." Id. at 232 . She was also concerned with "the possibility of graft and unaccountability in public welfare." Id.

113 See Samuel D. Warren \& Louis D. Brandeis, The Right to Privacy, 4 HARv. L. REV. 193 (1890) (describing the nature and extent of the protection afforded to an individual's person and property); see also Anita Allen \& Erin Mack, How Privacy Got Its Gender, 10 N. ILL. U. L. REV. 441, 457-60 (1990) (critiquing Warren and Brandeis for exploiting 19th-century attitudes about women as people with "special modesty" largely confined to the home).

${ }^{114}$ See UNIFORM CONSUMER CREDIT CODE $\$ 3.501$ to 3.505 (1974); FTC Commercial Practice Rule, 16 C.F.R. $\$ 429.1$ (1994) (codifying the duties of door-todoor salespersons). The likelihood that the salesperson is a man and the consumer is a woman, combined with the fact that the transactions generally occur in the context of the home, where the host is conventionally cordial, help to explain these rules. 
organization societies themselves came into existence for the purpose of coordinating sprawling private charities. Contemporary political discussions about human services are preoccupied with the issues of service integration and coordination, dramatized by what may be a story of urban folklore about the family that received nine different home visitors in one week and finally left the home, with hopes that the visitors would then talk with each other. ${ }^{114}$ Beyond the usual worries about unresponsive and cumbersome bureaucracies, these charges are especially telling if they apply to home visiting programs that treat the genuine human relationship of caring, friendship, and support as central to their mission. Therefore, a general resistance to human services programs, because of their tendency to resemble bureaucratic structures, gains special force when home visiting is under consideration.

One final historical source of opposition to home visiting comes from those who argue that the resources used to pay the visitors would be better used by the families themselves. ${ }^{115}$ Seeing home visitors as potentially intrusive and as arms of bureaucracies only adds to the claim that economic redistribution is what poor families or at-risk families really need-not redistributions that support middle-class professionals. One might respond that money alone will not help a young mother learn about child nutrition and child development or learn to overcome substance abuse or to avoid abusing her child. There is, however, a telling convergence between this criticism and the advice manual to home visitors written at the turn of the century, which urged against any material help because it would undermine the self-reliance of the poor. ${ }^{116}$

114 See Douglas J. Besharov, The Moral Voice of Welfare Reform, RESPONSIVE CoMmunITY, Spring 1993, at 13, 13 (citing the 1990 Edna McConnell Clark Foundation Annual Report, which discusses a scenario in which nine social workers simultaneously appeared at the household of a troubled family).

${ }^{115}$ See Robert Halpern et al., The Child Survival/ Fair Start Initiative in Context, in FAIR START, supra note 50, at 246, 253-54.

${ }^{116}$ See Charles B.P. BOSANQUeT, A HANDY-BOOK FOR Visitors OF THE POOR IN LONDON 15, 23 (London, Longmans, Green \& Co. 1874) (discouraging home visitors from inducing the poor to rely on them and stating that "more real good is done by inducing the Poor Law authorities to do their work well than by doing it for them"). Mary Richmond argued that both "income altruism" and "service altruism" are needed by the poor. MARY E. RICHMOND, THE GOOD NEIGHBOR IN THE MODERN CrTY 17-18 (spec. Philadelphia ed. 1908). By 1908, Mary Richmond would have responded that poverty has both personal and social causes that act upon one another, but that character is at the very center of the problem, and that tending to character is what her home visitors should do while becoming friends to the families they visited. 


\section{Recasting the Problem}

Despite good evidence that home visiting is a useful form of family support, public and private policymakers in the United States have not widely adopted home visiting, with the exception of a few states and localities. I have attributed this failure to (1) the contrasting styles and approaches to knowledge that distinguish social scientists from policymakers; (2) the absence of constituencies to support home visiting in the face of policy cycles of reform and retrenchment; and (3) cultural and historical sources of resistance to what may be perceived as an intrusive, insensitive, controlling, bureaucratic strategy.

On this basis, many could conclude that home visiting is not a good idea or a feasible one. I am not so ready to give up, however, because I actually find the evidence for its usefulness compelling. Moreover, as a new mother myself, I understand very well why some advocates of home visiting describe childbirth as "the teachable moment" for new parents. It is a moment when people are open to learning and willing to accept help. Most new parents need help and most of our social structures do not provide it. The arrival of a child affords a moment when support may be needed, welcomed, and useful in connecting the parents to further sources of social support. If home visiting helps to prevent child abuse, assist infants who have special risks of physical or developmental delays, and connect parents with other health and social services or career options, so much the better. In light of evidence about the crucial significance of human relationships to people's physical and mental health, and the special stresses posed by parenting, a program that promotes social support seems an admirable response to a society too often characterized by isolation and fragmentation.

In addition, the idea of empowerment as central to workable social reforms is nowhere more appropriate than the context of parenting. Help for parents must mean helping them find their own abilities to parent. Parenting itself includes not only the direct provision of care but also the capacity to reach out for other resources the child may need. Teaching parents in ways that empower them to parent can model the mode of teaching so that the parents can in turn-and over time-empower their own children. ${ }^{117}$

${ }^{117}$ See Young, supra note 102, manuscript at 24 (linking this concept of empowerment to a parental model of the ethic of care); $c f$. THOMAS E. WARTENBERG, THE FORMS OF POWER 183-201 (1990) (evaluating the transformative use of power, 
Research offers valuable lessons, but I believe we can learn not only from social science but also from experience. Both the benefits of home visiting and the experience of failures to adopt it widely suggest that one mistake has been the targeting of home visiting exclusively to "at-risk families." This stigmatizes the program and participation in it. It also renders the development of supporting constituencies very difficult. Few people want to organize politically to support a program on the grounds that they or their children are "at risk." Nor do many others want to organize on behalf of the "at-risk" group, however that is defined. Avoiding the danger of stigma and seeking a large constituency both call for universally available home visiting that leaves participation as a voluntary matter. With good information about home visiting services provided either through prenatal care settings or maternity hospitals, such programs could become the norm that everyone expects and welcomes.

There are more lessons from experience, however. The experiences of home visiting early in the century, contrasted with the more recent demand for community involvement and control in social services, cast doubt on the viability or legitimacy of programs imposed from central locations. Moreover, the needs of local communities vary in light of the existing sets of services, kinds of people available to be visitors, and even the acceptability of the home as a location for providing services. ${ }^{119}$ The Ford Foundation's experiment in funding home visiting programs in particular suggests that local communities have varied needs and perceptions. ${ }^{120}$ Abandoning one model and forgoing central control means losing easy forms of accountability, but opens up room for what those in the 1960s would have called community empowerment, and those in the 1990 s might call community ownership. ${ }^{121}$

I propose a new kind of partnership between social scientists and local communities. Social scientists could help members of local communities conduct their own research into the needs and

whereby a dominant agent infuses a subordinate agent with skills that undercut the power differential between the parties).

${ }^{119}$ See Larner et al., supra note 48, at 10-17; see also Slaughter-Defoe, supra note 101 , at 172.

${ }^{120}$ See Larner et al., supra note 48 , at $11-13$.

121 This might be a way to deal with the calls to alter assumptions about privacy that many advocates of home visiting currently make. See Halpern et al., supra note 116 , at 256 (discussing community-based services). 
wants of people in their communities for social supports for pregnant women and new parents. The very process of conducting such research can assist in building a sense of community where it is lacking and constructively address the specific constellation of attitudes and resources in the community. Community organizations, local governments, and nonprofit agencies could work together on the research projects and gain the power that comes with knowledge. They could also use the research stage to build support for the programs they then plan. Efforts to combine existing funding streams or advocate new ones would frame a larger agenda once those programs are designed. ${ }^{121}$

Planning the specific shape of a family support, or coordinating existing programs, would similarly provide a context for strengthening community bonds and commitment. Some communities may decide to adopt home visiting but use local community members as volunteer visitors; others may want to pay local community members; others may prefer professionals or even volunteers from other communities. ${ }^{122}$ Some communities may decide that home visitors should become advocates or community organizers. Some may prefer models that depart considerably from home visiting: community drop-in centers or school-based parenting support centers are already vital in some locales. One town has already experimented with setting aside one apartment in public housing complexes to serve as a parent-support center, using this space for what otherwise would be a "home visit." If

121 See id. Working out ways to tap into federal funds while assuring local options and local governance remains a large task here as elsewhere in government programs. The crucial impact of funding sources and governance structures on the motivation and quality of those involved at the ground level has been well-articulated. See, e.g., Judith A. Trolander, Settlement Houses and the Great Depression 148-58 (1975) (blaming the decline in the settlement movement in part on the shift from volunteer and politically active reformers to paid professionals and centralized funding).

${ }^{122}$ Based on his reading of the evidence, David Olds claims that the more successful programs utilize nurses. See David L. Olds, Home Visitation for Pregnant Women and Parents of Young Children, 146 AM. J. DISEASE OF CHILDREN 704, 707 (1992). Others prefer lay-trained nonprofessionals, and still others specifically recommend parents. See HARVARD FAMILY RESEARCH PROJECT, supra note 54, at 24. Most observers recommend intensive training and supervision regardless of the background of the visitors. See WASIK ET AL., supra note 1, at 91-119; Barbara H. Wasik, Staffing Issues for Home Visiting Programs, FUTURE OF CHILDREN, Winter 1993, at 140 . A basic ability to form a meaningful relationship seems the most essential quality for a visitor. See id.

${ }^{123}$ This example was offered during the American Association of Arts and Sciences Initiatives for Children Conference on Home Visiting, Oct. 19, 1993. 
pursued, new and important questions surface for professional social scientists. How do people identify "their community"? What processes can be crafted for designing inclusive and constructive studies and programs? What elements of successful home visiting programs can be transplanted to become parts of other kinds of programs? How can social scientists work directly with local communities, including local policymakers, and those who do not now make policy, but who consume it or become victimized by it?

If social scientists forged these kinds of collaborations, they would, in a real sense, return to their roots, but in doing so also learn from intervening experience. For the origins of American social science lie, at least in part, in the work of friendly visitors and settlement workers. Mary Richmond's Social Diagnosis laid the groundwork for sociology in the United States, as much as did her counterparts, Beatrice and Sidney Webb, in England. Jane Addams and her colleagues at Hull-House invented methods of survey research as well as curricula that became the core of the School of Social Service Administration at the University of Chicago. Similar links between settlement work and the growth of American social science have been documented in recent, fascinating histories. ${ }^{124}$

Yet in their conversion to academic disciplines, the social sciences lost their commitment to action and reform. In undertak-

An analogous program emphasizing reading as a focal point for involving parents in their children's education places college students within public housing projects. See Leadership, Education, \& Athletics in Partnership for New Haven Youth, Creating a New Haven for Our Children (1994) (unpublished grant proposal, on file with author).

${ }^{124}$ See, e.g., CosTiN, supra note 81, at 184-203 (recounting the critical role of settlement workers Edith Abbott and Sophonisba Breckinridge in the transformation of social work from a charitable and settlement activity to a professional training program housed in a research university); CRUNDEN, supra note 86, at 65-67 (tracing academic social science views about environmental determinism and democracy to the Hull-House settlement experience); FEFFER, supra note 84, at 160-61 (examining how John Dewey, George Herbert Mead, and other academics tested and articulated a theory of the mind's immanence in history and human action in conjunction with their involvement with the settlement-house movement); ELLEN FITZPATRICK, ENDLESS Crusade: WOMEn Social SGientists AND Progressive Reform 166-200 (1990) (exploring dual commitments of Sophonisba Breckinridge and Edith Abbott to social research and progressive reform). This close connection declined as academic social scientists distanced themselves from the settlement-house movement and social reform more generally. The increasing professionalization of social science included a commitment to objectivity construed as balanced views, distanced from the public and from politics. See JOHN H. EHRENREICH, THE ALTRUISTIC IMAGINATION: A HISTORY OF SOCLAL WORR AND SOCLAL POLICY IN THE UNITED STATES 76-77 (1985); DOROTHY ROSS, THE ORIGINS OF AMERICAN SOCIAL SCIENCE 158-160 (1991). 
ing the search for validity as an objective methodology, academic social sciences rejected social action. ${ }^{126}$ Perhaps this change manifested itself in a gender war, as the male-dominated academy displaced in new departments of social sciences the vital role of women in social welfare. I leave it to others to speculate how this gender division may have affected the soul of the social sciences. But I suggest that the gap between social sciences and policy was born during that era and that reuniting social scientists and communities would rebuild the bridge. Maintaining the rigor of methodologies developed in the meantime, while putting them to the service of community members, could reinvigorate the vision of democracy that animated the early American social scientists. In the process, new social bonds across communities could form for the mutual benefit of those involved. ${ }^{127}$

What would Judge Bazelon say about this? I think he would relish the picture of experts in social science facing the questions from people in local communities. Judge Bazelon loved to quote Thomas Jefferson's reply to those who worried about the complexity of issues that common people could not understand. Our task, said Jefferson, is to educate them so they can understand. When what is at stake is the health and welfare of common people, as well as their own voluntary participation in and support for programs to assist them, experts must learn to communicate with and assist the people. Judge Bazelon also would likely ask, in the long period called the meantime, what can be done? I hope that question prods many of us to work now to learn from experience and to help families and children in this country.

${ }^{126}$ For but one example of what must have been countless instances of conscious and unconscious depoliticization of social science, see WESTBROOK, supra note 104, at 91-92 (noting that social scientist John Dewey advised his colleagues to use dispassionate, depersonalized approaches to controversial questions about society). Contemporary social scientists themselves seem divided between those who seek neutrality and quantitative measures and those who pursue human connection and qualitative measures. See, e.g., Deborah Stone, Helter Shelter, NEw REPUBLIC, June 27, 1994, at 29, 30 (reviewing The Homeless by Christopher Jencks and Tell Them Who I Am: The Lives of Homeless Women by Elliott Liebow and examining techniques for studying the homeless). Both kinds may make important contributions to the policy process, and yet the motivation to seek reforms that respect other human beings may crucially depend upon retaining a sense of human commonality. See id. at 34 .

${ }^{127} C$. Halpern et al., supra note 116, at 246 (discussing community-based services). 